\title{
Enzymes of polyamine biodegradation pathway in amniotic fluid during the pregnancy compared with values of $\mathrm{L} / \mathrm{S}$ ratio
}

\author{
Gordana Bjelakovic ${ }^{1}$, Dusica Pavlovic ${ }^{1}$, Gordana Kocic ${ }^{1}$, Ivana Stojanovic ${ }^{1}$, Tatjana Jevtovic Stoimenov *11, \\ Dusan Sokolovic ${ }^{1}$, Marija Bjelakovic ${ }^{2}$, Petar Miladinovic ${ }^{3}$ \\ ${ }^{1}$ Institute of Biochemistry, Faculty of Medicine, University of Nis, Nis Serbia \\ ${ }^{2}$ Institute of Anatomy, Faculty of Medicine, University of Nis, Serbia \\ ${ }^{3}$ Clinic of Obstetric and Gynecology, Clinical Center and Faculty of Medicine, University of Nis, Serbia \\ *Corresponding author E-mail: tjevtovic@yahoo.com
}

Copyright @ 2015 Gordana Bjelakovic et al. This is an open access article distributed under the Creative Commons Attribution License, which permits unrestricted use, distribution, and reproduction in any medium, provided the original work is properly cited.

\begin{abstract}
Background: During the pregnancy the amount of polyamines spermine, spermidine and putrescine, rise rapidly in amniotic fluid. Polyamine oxidase (PAO) represents one of the key enzymes in catabolic pathway of polyamines. PAO catalyzes the oxidative deamination of spermine ( $\mathrm{Sp}$ ) or spermidine (Spd). The literature data documented that serum PAO activity increases in pregnancy. Diamine oxidase (DAO), histaminase, catalyses the oxidation of diamine putrescine or histamine. DAO is present in high concentrations in amniotic fluid. Amniotic fluid is the protective liquid for the baby in the mother's uterus. The determination of the lecithin to sphyngomyelin (L/S) ratio is by far the most widely used and accepted method to assess the fetal lung immaturity. The idea of the present study was to elucidate the polyamine metabolism in amniotic fluid during the pregnancy, through investigation of polyamine oxidase (PAO) and diamine oxidase (DAO) activities, and to compare their activities with the values of lecithin/ sphingomielin ratio (L/S) ratio.

Methods: The study included 170 pregnant women. The amniotic fluid samples were obtained using amniocentesis. The values of L/S ratio were estimated by a thin layer chromatography. PAO and DAO activities were measured by the spectrophotometric methods.

Results: Our results confirmed that amniotic fluid possess PAO and DAO activity. The activities of both enzymes in amniotic fluid samples increase in parallel with the L/S ratio increase. Diamine oxidase activity was higher than polyamine oxidase activity.

Conclusions: DAO and PAO activities may serve as markers of fetal lung maturity.
\end{abstract}

Keywords: Amniotic Fluid; Polyamine Oxidase Activity; Diamine Oxidase Activity; Lecithin/Sphingomyelin (L/S) Ratio; Women; Pregnancy.

\section{Introduction}

Polyamines - spermine, spermidine and putrescine are normal cellular constituents. As polycations, at physiological $\mathrm{pH}$, they interact with negatively charged molecules, such as DNA, RNA, proteins and phospholipids. They play multiple roles in cell growth, survival and proliferation [1-7]. The recent data demonstrate a primary function of the spermidine and spermine in the regulation of translation in mammalian cells [8], [9]. Polyamines are the subjects of intensive research in order to elucidate their functions and the involvement in physiology. "Polyamines are doing some important things, but we do not know what they are" [5], [7], [10-14].

It is well established that during the pregnancy the amount of polyamines rise rapidly in placenta and other tissues, in amniotic fluid, serum and urine [15-20], both in women and animals.

Polyamine oxidase (PAO; EC 1.5.3.11), a FAD containing enzyme, found in all vertebrate tissues and biological fluids, represents one of the key enzymes in catabolic pathway of polyamines. Polyamine oxidase (PAO) catalyzes the 
oxidative deamination of spermine ( $\mathrm{Sp}$ ) or spermidine $(\mathrm{Spd})$, producing spermidine or putrescine depending of substrate nature [21-24]. It is well documented that serum PAO activity increases in pregnancy [25], [26].

DAO, histaminase (EC, 1.4.3.6), a copper-containing enzyme catalyses the oxidation of diamine putrescine or histamine, producing GABA or MDA [27], [28]. GABA, synthesized from putrescine, is well known to function as an inhibitory neurotransmitter in the central nervous system [29], [30].

High diamine oxidase activities in placenta, serum and urine have been demonstrated during normal pregnancy [15], [16], [28], [31], [32]. DAO is present in high concentrations in amniotic fluid. It is produced by placental decidual cells and increases during pregnancy. Thats why DAO test is one of the first biochemical tests for the diagnosis of prelabor rupture of the membranes (PROM) [33-37]. Plasma diamine oxidase level correctly predicted the outcome of the pregnancy [38-41]. Abnormal levels of this enzyme, in amniotic fluid were found in 50\% of the pregnancies in which severe disease was associated with fetal death [41-43].

Amniotic fluid (AF) is the protective liquid that surrounds the baby while it is in the mother's uterus. The essential function of amniotic fluid (AF) is to cushion the fetus. The fluid gives the fetus space to grow and allows it to undergo a 'physical' development. AF function is, also, to protect the fetus from trauma and to maintain temperature. It also has a minimal nutritive function [37], [42], [43]. This body fluid contains phospholipids, including phosphatidylcholin (lecithin), sphingomyelin, phosphatidylinositol and phosphatidylglyerol (PG), cholesterol, and a variety of proteins. Altogether, they compose surfactant, which is secreted by the fetal lungs into the amniotic fluid. Surfactant is required to decrease surface tension within the alveoli thereby preventing alveolar collapse of the lung at the end of expiration [44], [45]. The amount of these substances in the amniotic fluid changes towards the end of gestation in a manner related to fetal lung maturity [42], [45]. The lecithin/sphingomyelin (L/S) ratio is a biochemical test for measuring the maturity of baby's lungs. This test gives a unique ability to determine whether a baby will be able to breathe after delivery, or whether it will need the aid of a respirator.

The determination of the lecithin to sphingomyelin (L/S) ratio is by far the most widely used and accepted method to assess the fetal lung immaturity [48], [49]. It is based on the original observations that lecithin (but not sphingomyelin) in the fetal pulmonary secretions increases after 32 to 33 weeks' gestation and that neonatal RDS was uncommon after the L/S ratio reached 2.0, which occurs around 35 weeks in uncomplicated pregnancies. This cutoff has remained an accepted threshold for the determination of fetal pulmonary maturity. Infants who are born in the late preterm period (35-37 weeks' gestation) are at increased risk of respiratory morbidity compared to infants born at term [42], [44], [45]. The probability of neonatal RDS using both gestational age and the L/S ratio may aid in clinical decision making, concerning the timing of delivery [45].

The idea of the present study was to elucidate the polyamine metabolism in amniotic fluid during the pregnancy, through the investigation of polyamine oxidase and diamine oxidase activities, the enzymes of catabolic pathways of polyamines, and to compare their activities with the values of lecithin/ sphingomielin ratio (L/S) ratio.

\section{Materials and methods}

The study included 170 pregnant women with both normal and pathological pregnancies, 18-43 years old, who have been hospitalized at the Clinic for Obstetrics and Gynecology in Clinical Center, Faculty of Medicine, and University of Nis, Serbia.

The amniotic fluid samples were obtained using amniocentesis. Amniocentesis has been performed between $15^{\text {th }}$ and $42^{\text {nd }}$ week of gestation, using ultrasound as a guide for needle placement. A small amount of amniotic fluid was taken out. The hemorrhagic samples have not been used for this study. The samples of amniotic fluid have been centrifuged at $3000 \mathrm{rpm} / \mathrm{min}$. The upper layer of liquid was stored in refrigerator at $-20^{\circ} \mathrm{C}$. The samples were used for polyamine oxidase and diamine oxidase activities and lecitine/sfingomyeline values ratio (L/S) analyses.

L/S ratio was estimated by a thin layer chromatography using assay kit (Helena laboratory, Beaumont, Texas, USA). The L/S ratio of 0-1.5 points out the immature fetal lungs, the L/S ratio from 1.6 to 1.9 is considered to be borderline and, the L/S ratio over the 2.0 represents fetal lung maturity [46], [47].

PAO (spermine-tetrahydrochloride "Sigma" was used as substrate) and DAO (putrescine-dihydrochloride "Sigma" was used as substrate) activities were measured by the spectrophotometric method of Bacharach and Reaches [48], modified by Quash et al. [49]. One unit of the enzyme activity was defined as an increase in optical density of 0.100 at $660 \mathrm{~nm}$.

In parallel with the performance of the biochemical examinations, the clinical observation for the fetal maturity was done.

The study was approved by the detailed information of every enrolled pregnant mother and their written consent was obtained prior to the sample collection.

Statistics: The obtained results were statistically analyzed using Student's t-test applying the SPSS computer statistical program. All the results are presented as mean $\pm \square$ SD.

\section{Results}

Our results show that lecithin/sphingomyelin (L/S) ratio increases during the pregnancy. The highest values were found in the amniotic fluid obtained from the pregnant women during the third trimester of pregnancy (Fig 1). 


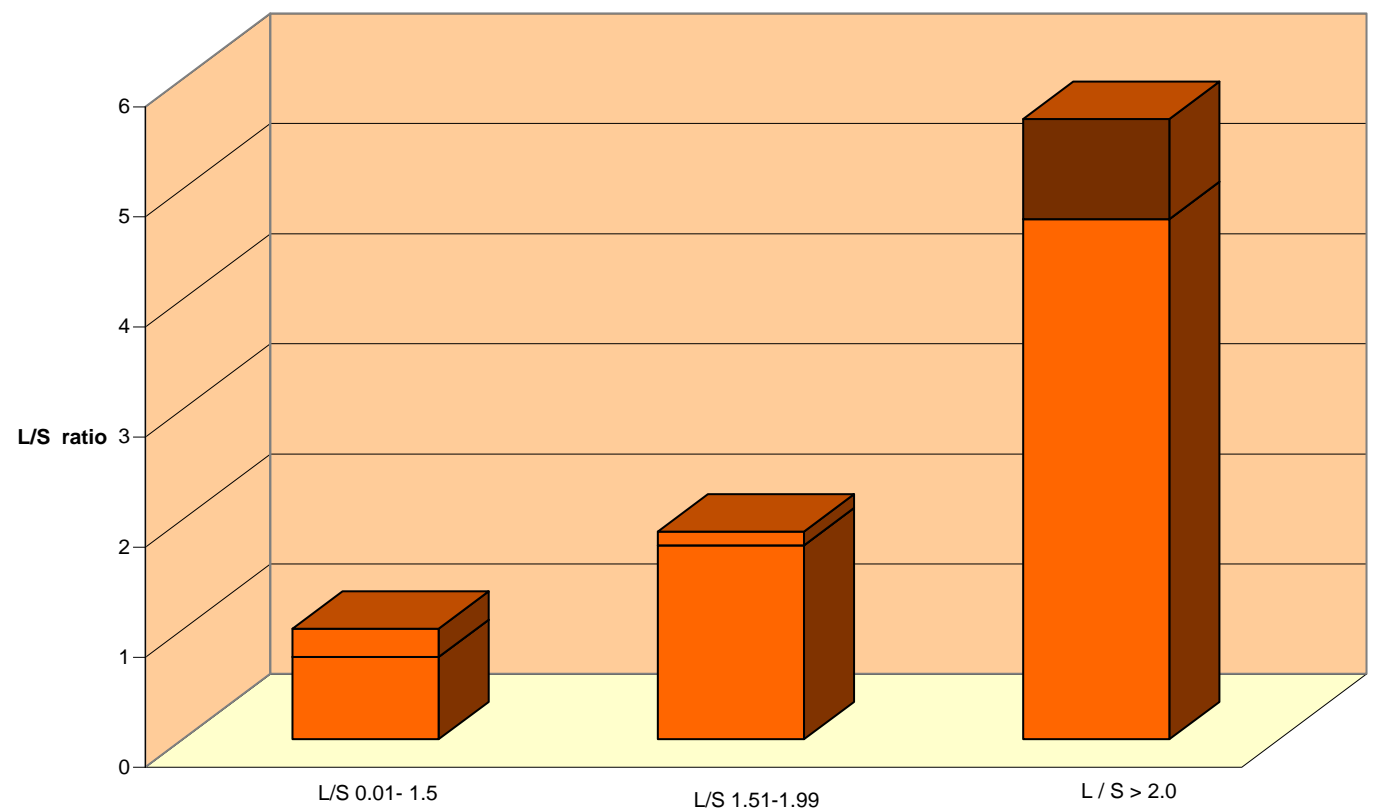

Fig. 1: Values of L/S Ratio in Amniotic Fluid Samples during the Pregnancy

Diamine oxidase activity in the amniotic fluid increases simultaneously with the increase of L/S ratio. There was an initial enzyme activity in amniotic fluid of immature embryos when L/S ratio was lower than 1.50 (the fetus signed as immaturus). In this period of gravidity, diamine oxidase activity was $0.51869 \pm 0.197 \mathrm{U} / \mathrm{ml}$ of amniotic fluid. During the process of maturation, DAO activity increases in correlation with an increase of L/S values. It is found that DAO activity was higher in amniotic fluids when L/S ratio values were between 1.51 to 1.99 , which means when fetuses were borderline. In this period of gravidity, DAO activity was $0.988043 \pm 0.373 \mathrm{U} / \mathrm{ml}$ of amniotic fluid. The highest DAO activity was detected when the values of L/S ratio were found to be 2.0 or higher, that is when the fetuses were considered mature; DAO activity was $3.946087 \pm 1.325 \mathrm{U} / \mathrm{ml}$ of amniotic fluid (Fig. 2).

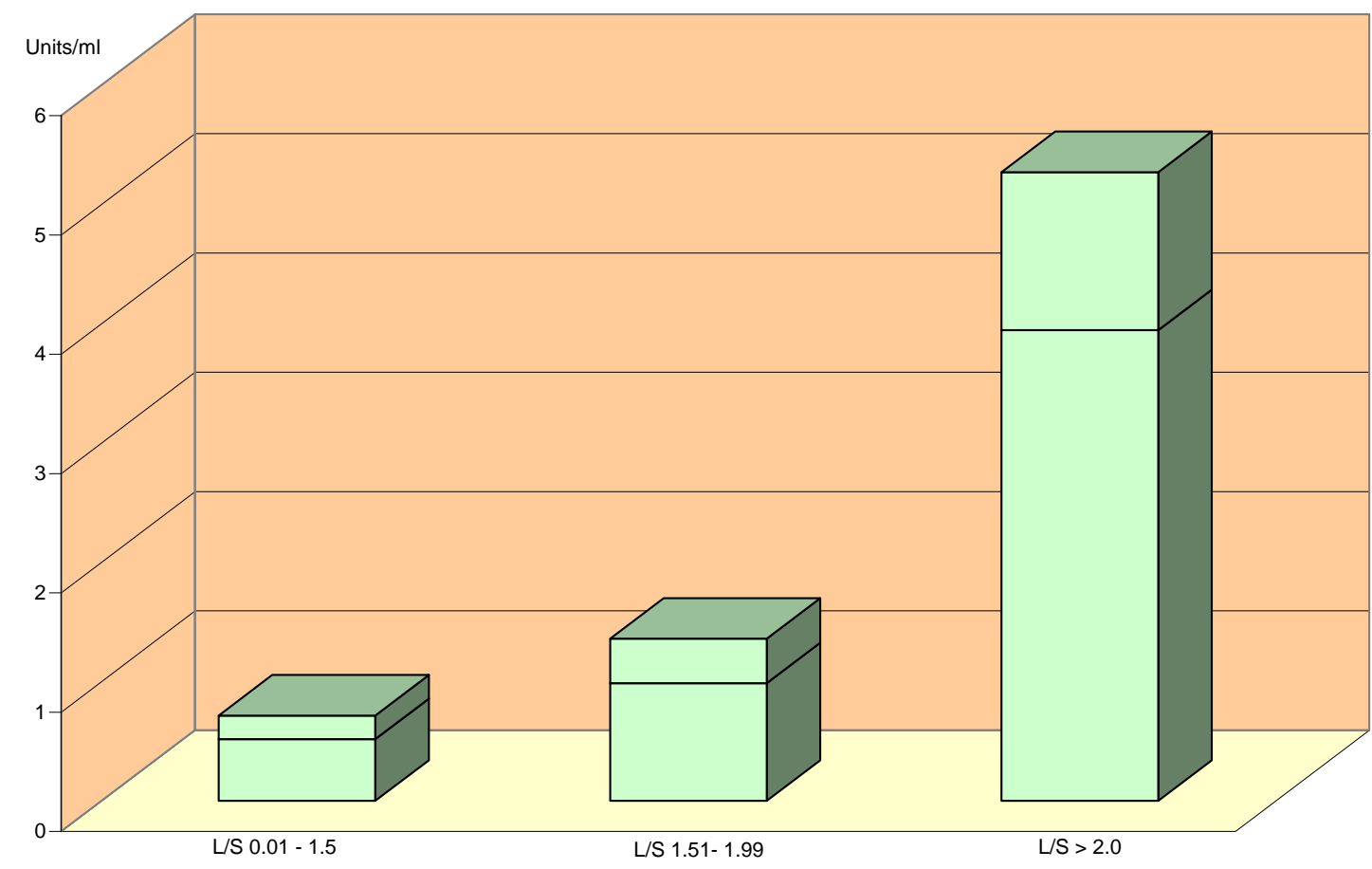

Fig. 2: Diamine Oxidase Activity in Amniotic Fluid during the Pregnancy (U/Ml) in Comparison with L/S Ratios.

Polyamine oxidase activity in the amniotic fluid increases simultaneously with the increase of L/S ratio also. There was an initial enzyme activity in amniotic fluid of immature embryos when L/S ratio was lower than 1.50 (the fetus signed as immaturus). In this period of gravidity, PAO activity was $0.30695 \pm 0.165 \mathrm{U} / \mathrm{ml}$ of amniotic fluid. During the process 
of fetus's maturation, PAO activity increases in correlation with an increase of L/S value. It is found that the PAO activity was higher in amniotic fluids with L/S ratio values between 1.51 to 1.99 , which means that fetuses were borderline; in this period of gravidity, PAO activity was $0.848333 \pm 0.377 \mathrm{U} / \mathrm{ml}$ of amniotic fluid. The highest PAO activity was detected when the values of $\mathrm{L} / \mathrm{S}$ ratio were found to be 2.0 or higher, that is when the fetuses were mature; PAO activity was $2.461739 \pm 0.767 \mathrm{U} / \mathrm{ml})($ Fig 3$)$.

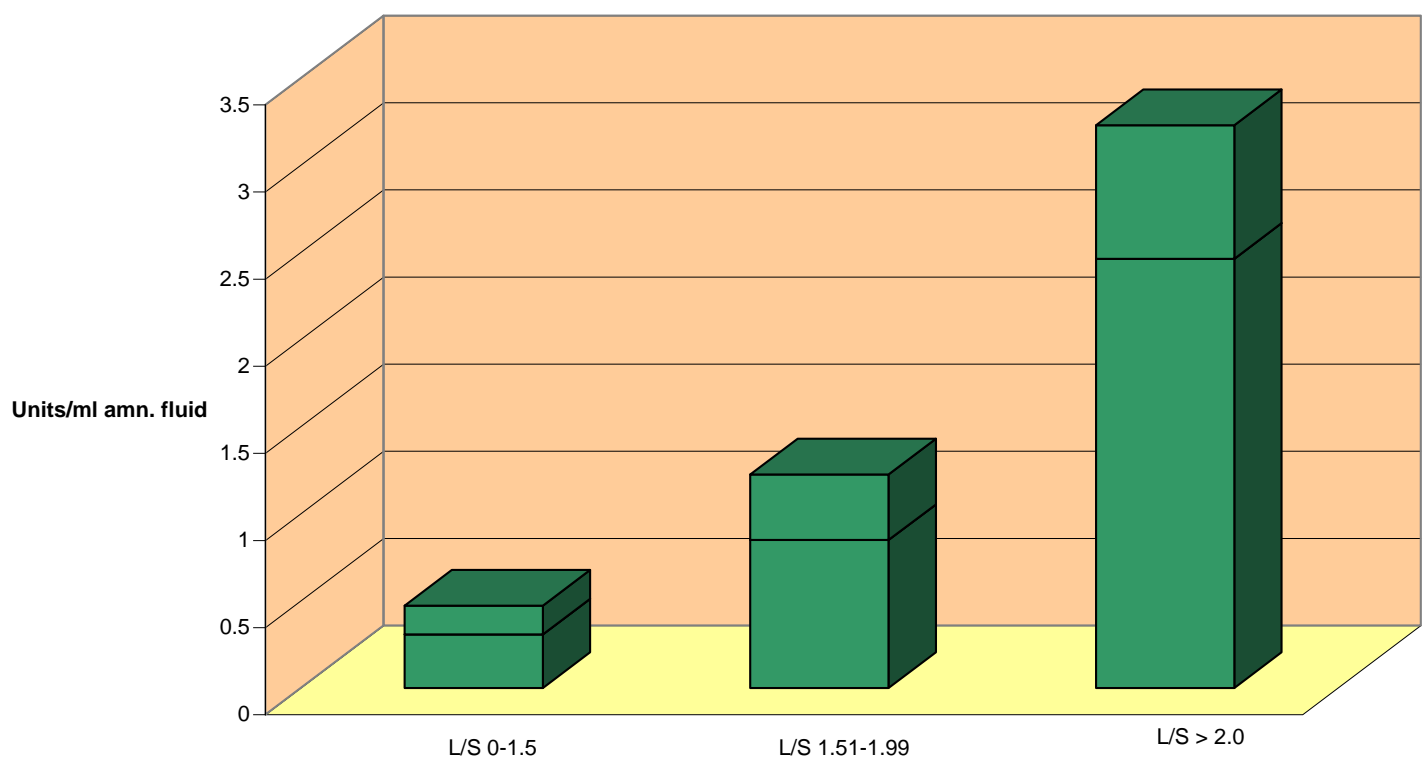

Fig. 3: Polyamine Oxidase Activity in Amniotic Fluid during the Pregnancy (U/Ml) in Comparison with L/S Ratios.

The increased levels of DAO and PAO activities correlate with the fetus's maturity (Fig 4).

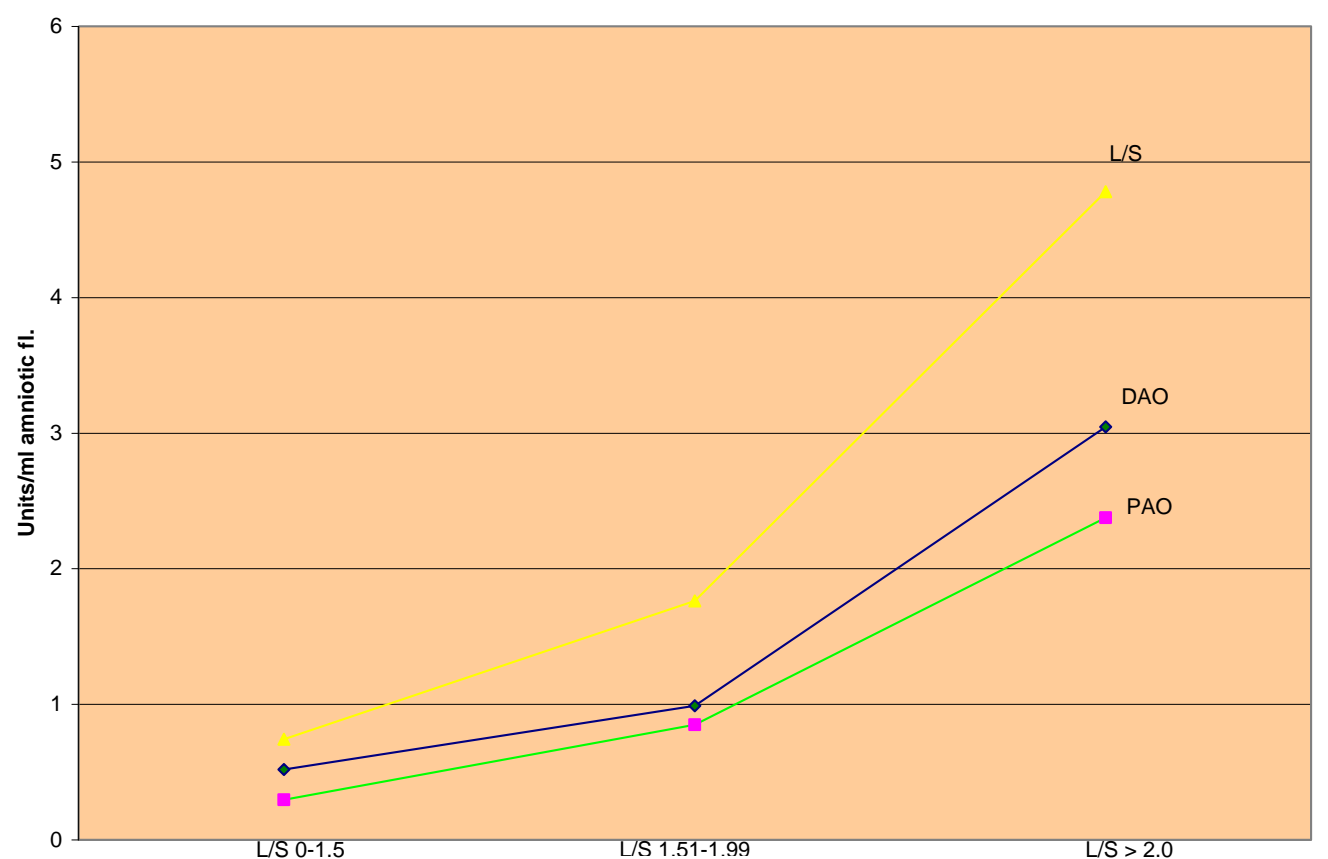

Fig. 4: The Dynamic of DAO and PAO Activities in Comparison with L/S Ratio in Amniotic Fluids during the Pregnancy.

\section{Discussion}

The three physiological polyamines, putrescine, spermidine and spermine, are all positively charged polycations at cellular $\mathrm{pH}$ and presumably function as stabilizing agents of RNA, DNA or negatively changed proteins. Polyamines 
are key regulators of angiogenesis, early mammalian embryogenesis, placental trophoblast growth, and embryonic development in the uterus [13], [50], [51].

The pregnancy of the rat brings about profound changes of the accumulation, biosynthesis and biodegradation of the polyamines in the reproductive tissues. The investigations of pregnant animals point out that placenta contained relatively high initial concentrations of spermine, which however, rapidly decreased until the term [15], [16], [52-54], probably due to an increased PAO activity, also proved in our examination. Polyamine oxidase, an integral component of the polyamine interconversion pathway, has an important place in the regulation of cellular polyamine levels [21-24]. There are many scientific data about PAO and DAO activity during women gravidity [25], [37].

Serum polyamine oxidase activity was significantly higher in the women having normal pregnancies Polyamine oxidase activity in amniotic fluid increased as pregnancy progressed. The enzyme found in amniotic fluid might be the consequence of diffusion from the decidua through the membranes [32], [38], [55]. According, the increasing of PAO activity during the pregnancy, observed in our investigation with amniotic fluid, may be explained in the context of maintaining the levels of polyamines in physiological ranges which support normal embryo development during the pregnancy. Placenta is rich in spermine and PAO. The interaction of polyamine oxidase with substrate is a part of maternal protective mechanism against fetal rejection. The increase of polyamine oxidase activity during the pregnancy, observed in our investigation, might have an immunoregulatory function in the placental bed, which might contribute to the protection of the fetoplacental unit from possible maternal immune rejection [26].

Also, the observed PAO activity changes in amniotic fluid may reflect the polyamine synthesis rate and the metabolic activity in human placenta during pregnancy.

DAO is synthesized by decidual and trophoblast cells, leading to high DAO levels during pregnancy [37], [56]. DAO activity, dramatically increased (10- and 20-fold) in maternal liver and kidney in the second half of pregnancy. The activity of diamine oxidase, increases up to 1000-fold in blood of pregnant women [38].

The behavior of DAO suggests that the enzyme plays an important role in the control of intracellular diamine concentration [19].

As histamine-degrading enzyme, DAO is produced in high amounts by the placenta and has been supposed to act as a metabolic barrier to prevent excessive entry of bioactive histamine from the placenta into the maternal or fetal circulation. The balance between histamine and DAO seems to be crucial for an uncomplicated course of pregnancy, [56-58].

The increase in diamine and polyamine oxidases activities is associated with an enhanced content of polyamines [59]. Thus, we suggest that the increased DAO and PAO activities in amniotic fluid may represent means by which the excess of polyamines can be removed and polyamine amounts controlled.

\section{Conclusion}

Based on the obtained results, we suggest that PAO and DAO activities in amniotic fluid, beside the other applicable biochemical and clinical tests, may serve as an important prerequisite for the accurate prediction of fetal lung maturity.

\section{Acknowledgement}

This work was supported by the grant from the scientific projects number 41018 and 31060 financed by the Ministry of Education and Science, Republic of Serbia.

\section{References}

[1] Cohen SS. A Guide to the Polyamines. Oxford University Press, New York, 1998 1-543.

[2] Tabor CW, Tabor H. Polyamines. Annu Rev Biochem 53 1984 749-790. http://dx.doi.org/10.1146/annurev.bi.53.070184.003533.

[3] Pegg AE. Mammalian polyamine metabolism and function. IUBMB Life 61(9) 2009 880-94. http://dx.doi.org/10.1002/iub.230.

[4] Igarashi K, Kashiwagi K. Modulation of cellular function by polyamines. Int J Biochem Cell Biol 42(1) 2010 39-51. http://dx.doi.org/10.1016/j.biocel.2009.07.009.

[5] Pegg AE, Casero RA. Current status of the polyamine research field.Methods Mol Biol 720 2011 3-35. http://dx.doi.org/10.1007/978-161779-034-8_1.

[6] Gerner EW, Meyskens FL. Polyamines and cancer: Old molecules, new understanding. Nat Rev Cancer 4(10) 2004 781-92. http://dx.doi.org/10.1038/nrc1454.

[7] Morgan DM. Polyamines. An overview. Molecular Biotechnology 11 1999 229-50. http://dx.doi.org/10.1007/BF02788682.

[8] Mandal S, Mandal A, Johansson HE, Orjalo AV, Park MH. Depletion of cellular polyamines, spermidine and spermine, causes a total arrest in translation and growth in mammalian cells. PNAS 110 (6) 2013 2169-174. http://dx.doi.org/10.1073/pnas.1219002110.

[9] Minois N, Carmona-Gutierrez D, Madeo F.Polyamines in aging and disease. Aging 3 (8) 2011 1-17.

[10] Coffino P, Poznanski A.Killer polyamines? J Cell Biochem 45(1) 1991 54-8. http://dx.doi.org/10.1002/jcb.240450112.

[11] Heby O. Role of polyamines in the control of cell proliferation and differentiation. Differentiation 19 1981 1-20. http://dx.doi.org/10.1111/j.1432-0436.1981.tb01123.x.

[12] Urdiales JL, Medina MA. Sanchez-Jimenez F. Polyamine metabolism revisited. European Journal of Gastroenterology \& Hepatology 13(9) 2001 1015-019. http://dx.doi.org/10.1097/00042737-200109000-00003. 
[13] Wallace MH, Frasaer VA, Hughes A. A perspective of polyamine metabolism. Biochem J $376 \quad 2003 \quad 1-14$ http://dx.doi.org/10.1042/BJ20031327.

[14] JanneJ, Alhonen L, Pietila M, Keinanen TA. Genetic approaches to the cellular functions of polyamines in mammals. Eur J Biochem 2712004 877-94. http://dx.doi.org/10.1111/j.1432-1033.2004.04009.x.

[15] Anderssonn CA, Henningssonn S, Rosengren E. Increased formatuion of diamine and polyamine in pregnant rat. J Physiol 285 1978 $311-324$. http://dx.doi.org/10.1113/jphysiol.1978.sp012573.

[16] Guha SK, Jänne J. The synthesis and accumulation of polyamines in reproductive organs of the rat during pregnancy. Biochim Biophys Acta (BBA) - General Subjects 437(1) 1976 244-252 http://dx.doi.org/10.1016/0304-4165(76)90366-4.

[17] Holtta E. Oxidation of Spermidine and Spermine in Rat Liver: Purification and Properties of Polyamine Oxidase? Biochemistry 16(1) 1977 91-100. http://dx.doi.org/10.1021/bi00620a015.

[18] Maudsley DV, Kobayashi Y. Biosynthesis and metabolism of putrescine in the rat placenta. Biochem Pharmacol $26(2) 1977$ 121-24. http://dx.doi.org/10.1016/0006-2952(77)90382-3.

[19] Piacentini M, Sartori C, Beninati S, Bargagli AM, Ceru-Argento MP. Ornithine decarboxylase, transglutaminase, diamine oxidase and total diamines and polyamines in maternal liver and kidney throughout rat pregnancy. Biochem J 234 1986 435-40.

[20] Chan YW, Seale WT, Shukla BJ, Rennert MO. Polyamine conjugates and total polyamine concentrations in human amniotic fluid. Clin Chim Acta 91 1979 233-41. http://dx.doi.org/10.1016/0009-8981(79)90479-0.

[21] Seiler N. Catabolism of polyamines. Amino Acids 262004 217-33. http://dx.doi.org/10.1007/s00726-004-0070-z.

[22] Seiler N, Raul F. Polyamines and apoptosis. J Cell Mol Med 9(3) 2005 623-42. http://dx.doi.org/10.1111/j.1582-4934.2005.tb00493.x.

[23] Vujic S, Diegelman P, Bacchi CJ, Kramer DL, Porter CW. Identification and characterization of a novel flavin-containing spermine oxidase of mammalian cell origin. Biochem J 3672002 665-75. http://dx.doi.org/10.1042/BJ20020720.

[24] VujicS, Liang P, Diegelman P, Kramer DL,Porter CW.Genomic identification and biochemical characterization of the mammalian polyamine oxidase involved in polyamine back-conversion. Biochem J 3702003 19-28. http://dx.doi.org/10.1042/BJ20021779.

[25] Illei G, Morgan DML. Serum polyamine oxidase activity in spontaneous abortion BJOG: An Int J Obst Gynaecol 89 (3) $1982199-201$. http://dx.doi.org/10.1111/j.1471-0528.1982.tb03613.x.

[26] Morgan DML,Illei G. Polyamine-polyamine oxidase interaction: part of maternal protective mechanism against fetal rejection. Br Med J 280 1980 1295-297. http://dx.doi.org/10.1136/bmj.280.6227.1295.

[27] Anderson CA, Henningsson S, Persson L, Rosengren E. Aspect on diamine oxidase activity and its determination. Acta Physiol Scand 102 1978 159-66. http://dx.doi.org/10.1111/j.1748-1716.1978.tb06059.x.

[28] Wolvekamp MC, de Bruin RW.Diamine oxidase: an overview of historical, biochemical and functional aspects. Dig Dis 12(1) $19942-14$. http://dx.doi.org/10.1159/000171432.

[29] Konishi H, Nakajama T, Saano I. Metabolism of Putrescine in the Central Nervous System. J Biochem 81(2) 1977 355-60.

[30] Caron PC, Cote LJ, Kremzner LT. Putrescine, a source of gamma-aminobutyric acid in the adrenal gland of the rat. Biochem J 251(2) 1988 $559-62$.

[31] Crabbe CJM, Waight DR, Bardsley GW. Human placental diamine oxidase. Biochem J 1551976 679-87.

[32] Southern AL, KobayashiY, Brenner P, Weingold AB. Diamine oxidase activity in human maternal and fetal plasma and tissues at parturition. J Appl Physiol 20(5) 1965 1048-051.

[33] Torok EE, Brewer J I, Dolkart RE. Serum Diamine Oxidase in Pregnancy and in Trophoblastic Diseases. J Clin Endocrinol Metab $30(1) 1970$ 59-65. Doi: 10.1210/jcem-30-1-59 http://dx.doi.org/10.1210/jcem-30-1-59.

[34] 34. Ward H, Whyley GA, Millar MD. The Value of Amniotic Fluid Diamine Oxidase Estimations in the Management of Severe Rhesus IsoImmunization. Acta Obstetricia ET Gynecologica Scandinavica 55(1) 1976 63-68. http://dx.doi.org/10.3109/00016347609156786.

[35] Crabbe CJM, Waight DR, Bardsley GW. Human placental diamine oxidase. . Biochem J 155 1976 679-87.

[36] Gahl AW, Raubertas FR, Vale MA, Golubjatnikov R. Maternal serum diamine oxidase in fetal death and low birth-weith infants. Br J Obs Gynaecol 891982 202-07. http://dx.doi.org/10.1111/j.1471-0528.1982.tb03614.x.

[37] Wiberg-Itzel E. Lactate Level in Amniotic Fluid, a New Diagnostic Tool From Preconception to Postpartum, Dr. Stavros Sifakis (Ed.), (2012) Chapter 14 221-224. ISBN: 978-953-51-0353-0, InTech, Available from: http://www.intechopen.com/books/from-preconception-topostpartum/lactate-level-in-amniotic-fluid-a-newdiagnostic-tool-in-dysfunctional-labor.

[38] Holinka CF, Gurpide E. Diamine oxidase activity in human decidua and endometrium. Am J Obstet Gynecol 150(4) 1984 359-63. http://dx.doi.org/10.1016/S0002-9378(84)80138-6.

[39] Southern AL, KobayashiY, Brenner P, Weingold AB. Diamine oxidase activity in human maternal and fetal plasma and tissues at parturition. J Appl Physiol 20(5) 1984 1048-051.

[40] Legge M, Hammond EM, Ncwsomc B J, Duff G B, Aickin DR. Maternal Serum Diamine Oxidase Activity in the Third Trimester. AsiaOceania Journal of Obstetrics and Gynaecology12 (4) 1986 493-98. http://dx.doi.org/10.1111/j.1447-0756.1986.tb00224.x.

[41] Legge M, Duff GB. Plasma diamine oxidase levels in pregnancy complicated by threatened abortion. J Clin Pathol 34(2) 1981 187-88. http://dx.doi.org/10.1136/jcp.34.2.187.

[42] Yurdakök M. Inherited disorders of neonatal lung diseases. Turk J Pediatr 46(2) 2004 105-14.

[43] Luo G, Norwitz ER. Revisiting amniocentesis for fetal lung maturity afterweeks' gestation. Rev Obstet Gynecol 1(2) 2008 61-8.

[44] Whitsett JA, Weaver TE. Hydrophobic surfactant proteins in lung function and disease. N Engl J Med 347 2002 2141-48. http://dx.doi.org/10.1056/NEJMra022387.

[45] Wijnberger LDE, de Kleine M, Voorbij HAM, et al. Prediction of fetal lung immaturity using gestational age, patient characteristics and fetal lung maturity tests: a probabilistic approach. Arch Gynecol Obstet 281(1) 2010 15-21. http://dx.doi.org/10.1007/s00404-009-1033-0.

[46] St Clair C, Norwitz ER, Woensdregt K, et al. The probability of neonatal respiratory distress syndrome as a function of gestational age and lecithin/sphingomyelin ratio. Am J Perinatol 25(8) 2008 473-80. http://dx.doi.org/10.1055/s-0028-1085066.

[47] Gluck L, Kulovich MV, Borer RC, Brenner PH, Anderson GG, Spellacy WN. Diagnosis of the respiratory distress syndrome by amniocentesis. Am J Obstet Gynecol109 (3) 1971 440-45.

[48] Bachrach U. Reches B. Enzymic assay for spermine and spermidine.Anal Biochem 171966 38-48. http://dx.doi.org/10.1016/00032697(66)90005-4.

[49] Quash G, Keolouangkhot T, Gazzolo L, Ripoll H, Saez S. Diamine oxidase and polyamine oxidase activities in normal and transformed cells. Biochem J 1771979 275-82.

[50] Pegg EA. Recent advances in the biochemistry of polyamines in eukaryotes. Biochem J 234 1986 249-62.

[51] Thomas T, Thomas JT. Polyamines in cell growth and cell death:molecular mechanisms and therapeutic applications. Cell Mol Life Sci 58 2001 244-58. http://dx.doi.org/10.1007/PL00000852.

[52] Reynolds LP, Redmer DA. Angiogenesis in the placenta. Biol Reprod 642001 1033-040. http://dx.doi.org/10.1095/biolreprod64.4.1033.

[53] Fozard JR, Part ML, Prakash NJ, Grove J, Schechter PJ, Sjoerdsma A, Koch-Weser J. L-Ornithine decarboxylase: an essential role in early mammalian embryogenesis. Science 208 (4443) 1980 505-508. http://dx.doi.org/10.1126/science.6768132.

[54] Kwon H, Wu G, Bazer FW, Spencer TE. Developmental Changes in Polyamine Levels and Synthesis in the Ovine Conceptus. Biol Reproduct 69(5) 2003 1626-634. http://dx.doi.org/10.1095/biolreprod.103.019067. 
[55] Illei G, Morgan DM. Polyamine oxidase activity in amniotic fluid and fetal membranes. Br J Obstet Gynaecol 87(5) 1980 413-15. http://dx.doi.org/10.1111/j.1471-0528.1980.tb04570.x.

[56] Maintz L, Schwarzer V, Bieber T, van der Ven K, Novak N. Effects of histamine and diamine oxidase activities on pregnancy: a critical review. Human Reproduction Update 14(5) 2008 485-95. http://dx.doi.org/10.1093/humupd/dmn014.

[57] Brew O, Sullivan MH. The links between maternal histamine levels and complications of human pregnancy. J Reprod Immunol 72 2006 94 107. http://dx.doi.org/10.1016/j.jri.2006.04.002.

[58] Beaven MA, Marshall JR, Baylin SB, Sjoerdsma A. Changes in plasma histaminase activity during normal early human pregnancy and pregnancy disorders. Am J Obstet Gynecol 1231975 605-09.

[59] Perin A, Sessa A, Desiderio MA. Response of tissue diamine oxidase activity to polyamine administration. Biochem J $2341986119-23$. 